\title{
Refusal of Home? Architecture Ex-Patriota
}

\section{David Beynon}

In 1999, the author was one of the designers of a competition-winning 'Home of the Future' (AlsoCAN Architects with Multiplicity, 1999a). This was a design that speculated on the idea of home in a future where itinerancy would become the prevalent mode of dwelling. In 2008, Interstices asks, 'What is it to refuse home?', a question that seems to assume that expatriation involves a deliberate estrangement from homeliness and its connotations. Springing from reflections on this question and ideas of future homes that came out of the competition entry, this paper explores the connection between expatriation and dwelling. The architecture of the expatriate is considered in a number of potential contexts: as a dwelling for a contemporary urban nomad, as a place for singular belonging ex-patriota and as part of the urban environment.

\section{The Slinky House}

You are an urban professional in the year 2021.

The project you are currently working on is terminated.

Your employment contract is therefore terminated.

To survive the ultra-rationalist $21^{\text {st }}$ century you, your current partner and your two children will, of necessity have to relocate to wherever your talents are in demand.

You rely on your bargaining skills to land another short-term postion: be it across town, country or the globe. (AlsoCAN Architects with Multiplicity, 1999a, 1999b)

In 1999, just before the Millennium Bug was supposed to wipe out the modern world, the author was part of a group of architects and designers who entered a competition to design a house of the future. This competition asked the question of how the idea of home might change by 2020 (Museum Victoria, 1999). The group's design, dubbed the 'Slinky House' after its resemblance to the coiled metal toy (Fig. 1), won the competition and received some publicity. The designers basked in their fifteen minutes of fame, spent their prize money and went back to their real work. However, the project was concerned with the question of architecture's place in a world of peripatetic workers and nomadic urban professionals. These concerns remain current, so the Slinky House is a suitable starting point for a discussion about questions of home, expatriation and architecture. 
Fig. 1: Slinky House, original competition entry sheet. Source: AlsoCAN Architects (David Beynon, Jane McDougall \& Andrew Morant) in conjunction with Multiplicity (Sioux Clark \& Tim O'Sullivan).

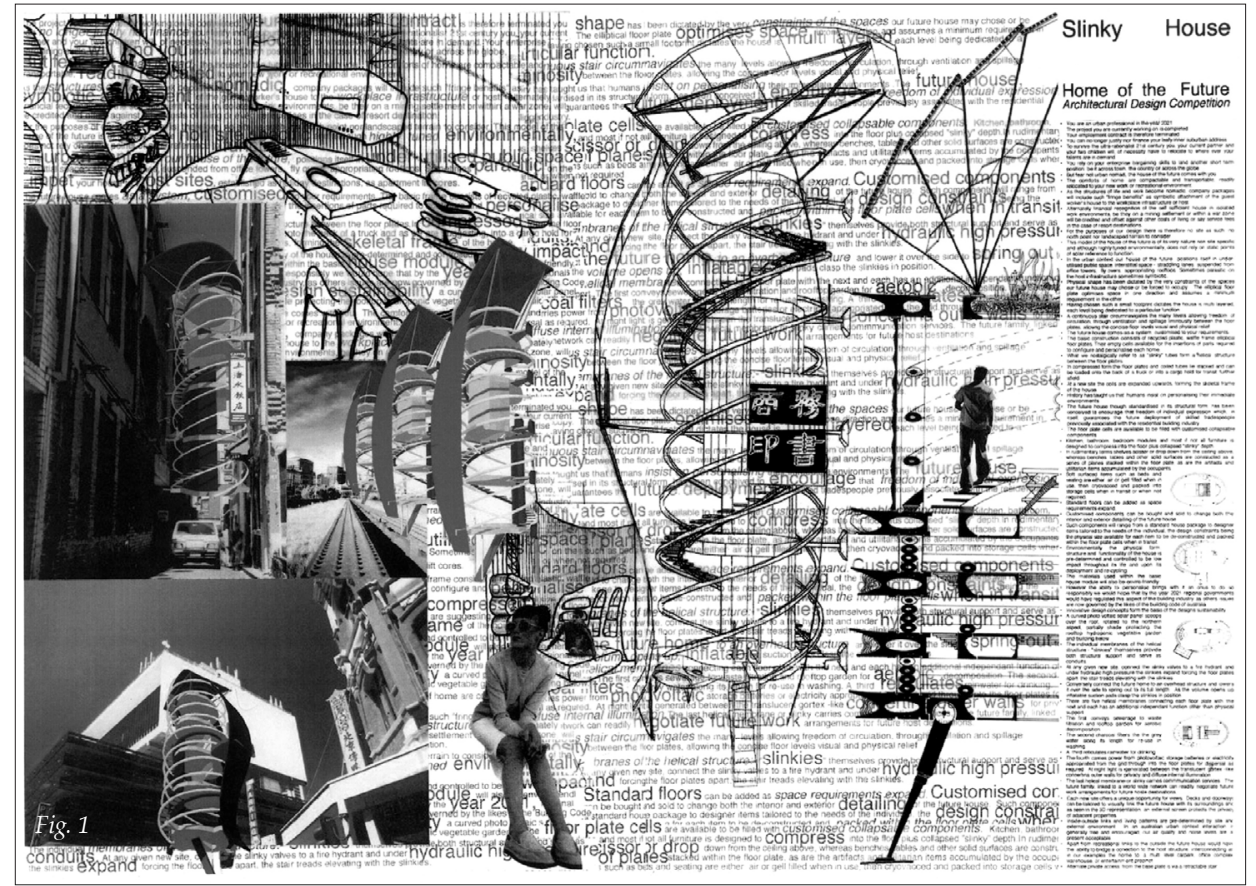

The competition entry proposed the following scenario. Urban professionals of the year 2021 would be employed on short-term contracts, potentially anywhere across the globe. The ability to remain mobile would be a key factor in making the most of opportunities. Correspondingly, the idea of dwelling as a permanent place, anchored geographically to a single location would become untenable. Instead, the Slinky House proposed a tubular, multi-storey dwelling that would be compactable and transportable.

Its structure and services could be attached to the workplace infrastructure of its inhabitants, or it could be self-supporting and self-sufficient. In an urban context, it could occupy under-utilized and interstitial spaces, straddling lanes, attaching limpet-like to sides of office towers, or appropriating their rooftops. Its physical shape - a series of elliptical recycled plastic floor plates connected by a surrounding stair structure - was devised to optimize ease of transport and differentiate functions and usage within (Fig. 2). Fittings and fixtures would be inserted in the cellular structure floor plates, customized to its inhabitant's requirements. 'Slinky' tubes wound helically around the stairs and the plates provided an expandable structure (Fig. 3). For transportation, the Slinky House would compress like a Chinese lantern, floor plates stacking flat on top of each other with the tubes coiled closely around them. It was also proposed that the Slinky House would facilitate the usage of solar power and recycling of water, so it could have a symbiotic rather than purely parasitic relationship with its building-host (one of the reviewers of the Slinky House described it as "tick-like") (Home of the Future Competition, 1999: 12-13). An image of the Slinky House shows it suspended in a narrow alleyway in Melbourne's Chinatown (Fig. 4). Inside, its occupier is connected both physically and virtually to the environment from which the Slinky hangs, until the day when his/her contract is completed. Then the Slinky is compacted, placed into a container and delivered to its next location. 

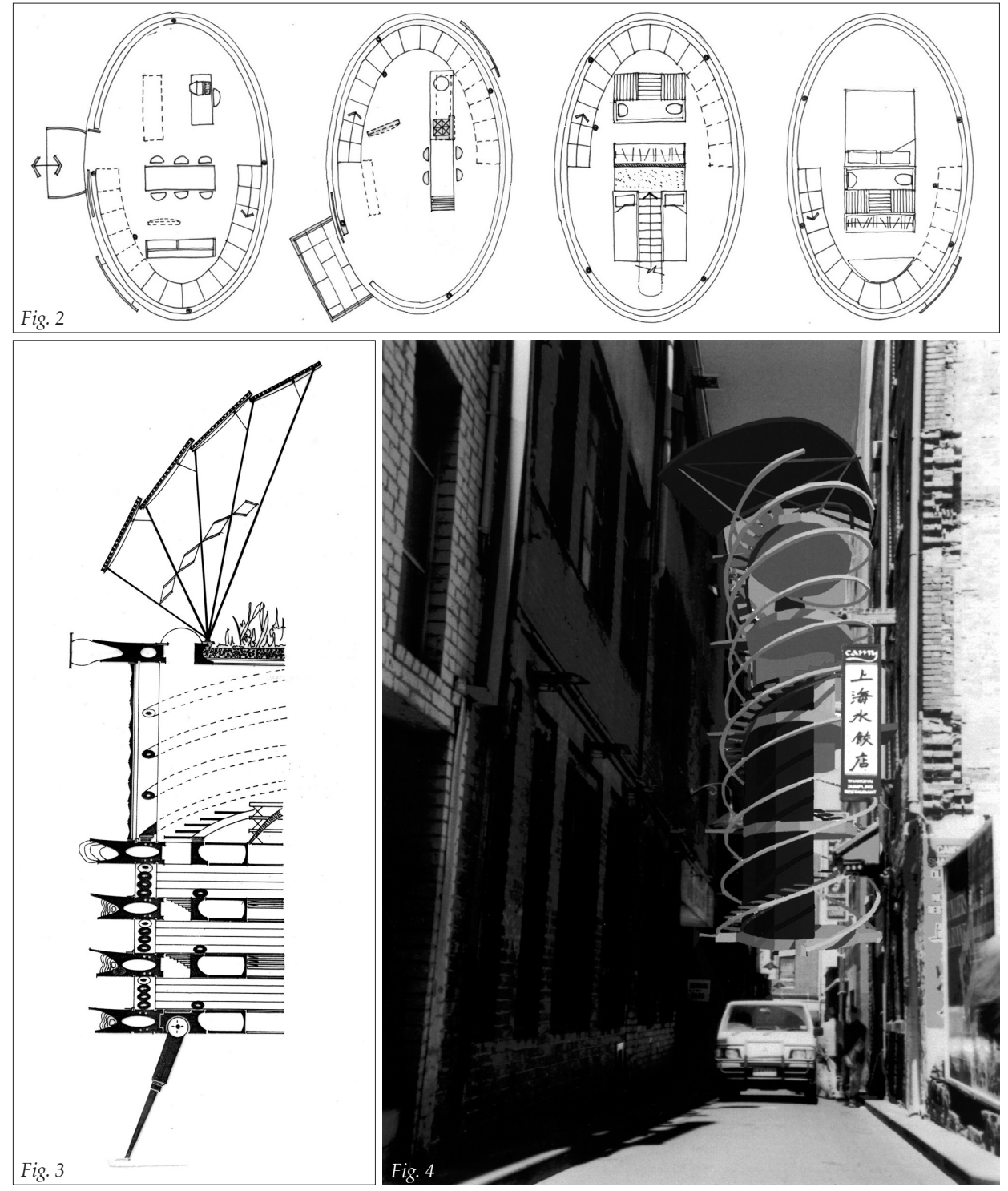

\section{Expatriates - At Home in the World?}

Expatriates are conventionally imagined as urban, applying their professional or business skills within the global economy according to opportunity and demand. They are the heirs to the world of colonial expansion and trade, and while as contemporary global urbanites they might not enjoy quite the exalted status of their colonial forbears, they are still a privileged class. They have, in Bourdieu's (1993) terms, an abundance of capital. Due to their education and background, they have both economic and social capital. This status enhances their cultural capital and engenders their symbolic capital to the point that in cities across the world, commerce, retail and architecture are influenced to serve their tastes and desires. In Singapore, for example, such recent developments as the increasing use of public and riverside spaces for drinking and dining owe part of their origins to its expatriate population. The space of the Singaporean wine bar occupies an ambiguous zone between local site and faraway idea in terms of its content (wine), its embodiment of such an environment for consuming it and the globalized bodies of its consumers. Neil Leach might refer to it as an aesthetic cocoon, an example of the globalized elite's reaction to the frag-
Fig. 2: Slinky House - possible floor plans. Source: AlsoCAN Architects with Multiplicity.

Fig. 3: Slinky House section. Source: AlsoCAN Architects with Multiplicity. Fig. 4: Slinky House in laneway setting. Source: AlsoCAN Architects with Multiplicity. 
mentation of contemporary cities, a retreat into aestheticized comfort, a kind of generic high-style environment inhabited worldwide by, as he puts it, "Wall-

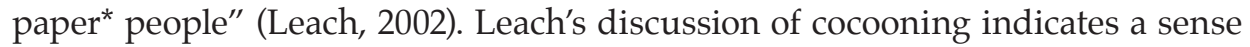
of belonging within shared spaces that can be generated by the globalizing of a particular kind of taste-culture. These postmodern cosmopolitans have their own aesthetic (and anaesthetic) environments in which to plug bodily in each city. In the absence of traditional ties of belonging, the Wallpaper* modern style signifies the presence of the like-minded, the like-dressed and the like-interested, in a reassuring environment of exquisite detailing and rarefied taste. Their collective presence in particular locations, such as along Singapore's waterfront, is demonstrative of what Appadurai has called translocalities, in which particular kinds of localities are generated that are sustained through the continual presence of outsiders (1996: 192).

Looking at this from a less Western perspective, another example of expatriate impact might be represented by the multitude of businesses in the vicinity of Australian universities that are patronized largely by a shifting population of international students. For instance, in the inner Melbourne suburb of Hawthorn, otherwise a bastion of the Anglo-Celtic middle-class, there exists around Swinburne University's campus a busy mixture of Indonesian and other Asian cafés and grocery stores, which provide much of the contemporary character of the area. While it might be arguable whether international students are expatriates, their increasing numbers, wealth and consumer influence suggest that they fulfil a similar role in their places of temporary settlement. The fact that the majority of international students in Australia are from various parts of Asia has traditionally been seen as indicative of Australia's position as an education provider. However, the physical changes engendered by their presence are indicative of a future in which cultural hegemony might be derived from other sources. Apart from such establishments as student noodle bars, the increasing number of businesses dealing in bubble tea, Japanese crepes, Hello Kitty merchandise, anime figurines and Canto-pop in Australian cities suggests the growth of Eastern-originated global trends that will easily counter the spread of wine bars and Wallpaper* people. However, whether exemplified by Singaporean wine bars or Melbournian bubble tea cafés, design operates as a code: understanding of the messages inherent in these spaces is signified by the dress and demeanour of the people who frequent them.

However, do such spaces correspond with the question, "What is it to refuse home?", posed in this issue of Interstices, and can the idea of home be engendered by a global network of designer bars, cafés and resorts? What of expatriates' actual living spaces? Despite the existence of expatriate-friendly public environments, a sense of place under expatriate conditions is necessarily conditional. For the contemporary expatriate, life is a process of mediating between physical and virtual realities. For the expatriate, even more than for the migrant, moving from one location to another is not so much a transfer of self to a new territory, as the repositioning of the physical body in another part of a web of visible and invisible connections. From most locations within this web, the same resources can be tapped, the same services used, the same entertainments enjoyed. The individuality of each location is arguably restricted to a layer of physical stimuli weather, local language, cuisine - that can be enjoyed, mediated or even virtually negated by globalized infrastructure. 
It could be argued that the existence of wine bars and bubble tea cafés in increasing numbers of cities worldwide indicates not the spreading of distinct cultural places but the merging of particular places in a continuous global non-place. In this continuum, the expatriate exists, as if in one of Augés airports, engaged in a constant process in which there is no real place, but only a series of procedures (Augé, 1995). However, such an argument places too much emphasis on the expatriate as a passive recipient of processes and stimuli. It suggests that globalized people emerge fully formed to fit their globalized environment, rather than this environment being in constant reformation and flux due to their agency. It also negates the possibility that the myriad small differences - including architectural differences - between actual places might be able to intervene, punctuating the smoothness of space with real difference. Despite the advances in electronic communications, physical locations still have to be settled and inhabited. Leach's proposition that aesthetic cocoons provide settings for such people to interact as communities - that such spaces provide not just ambience but also the conditions for human connection - suggests that expatriate appropriation of space can be productive.

\section{Mobile or Sedentary, Permanent or Ephemeral?}

Architecture - including that of Leach's Wallpaper* people and Melbourne's Asian students - is traditionally static. Architecture is usually the backdrop to action but not a participant in that action. It signifies permanence, aspirations towards the conquest of time. The notion of permanent settlement is the fundamental basis of cities, manifested in solidly immovable buildings and their defined surroundings, placed and codified by the boundaries of precincts, cities, states and nations. This is not just symbolic. Buildings stand as mute demarcation of territorial ownership, signifying the primacy of tenure and the status of landowners. Homelands are defined by the presence of homes. Homeland security is based on the secure permanence of homes. Architecture is not just complicit in these definitions. It is the embodiment of them.

However, of course this is not the only tradition of building. There has always been portable and ephemeral architecture, traditionally represented by the dwellings of nomads. Traditional nomads engage in periodic and cyclical movement for specific purposes, at defined times and across particular territories, dictated by climate, vegetation, and the habits of animals that they rear or hunt. Thus home, for the nomad, requires individual engagement with a much broader territory than for the sedentary. Dwelling either requires the constant construction of shelter, the periodic occupation of seasonal buildings or the development of mobile architecture. A nomadic definition of home has thus always been at odds with the permanently settled one.

The nomad's lack of allegiance to artificial boundaries, states or nations has always made them deeply suspect in the eyes of the settled and the landowning. This suspicion of the nomadic persists in contemporary societies, embodied in the stigma of vagrancy. The idea of homeless people offends many not through their empathy towards those unfortunate enough to be without a home, but because the presence of the mobile, the unplaced, is deeply disturbing to the settled. The homeless threaten the security of those with homes, in that they do not respect the sanctity of ownership or boundaries. They are dirty not because they have no place to wash, but because they are considered in Mary Douglas' 
definition to be matter out of place (1996: 35). This sense of place and ownership haunts discussions of belonging and home, implying that home has a specific and permanent place, and being outside that place - especially by choice - implies a rejection of home. It would appear that in the battle between the settled and the nomadic, the settlers have won the linguistic as well as the physical battle.

Yet do we not live in a world of unprecedented connectivity, in which it is possible to be virtually anywhere in the world and be instantaneously in communication with anywhere else? Have globalized economy and air travel not dissolved the old boundaries of ethnicity and nation? Is the expatriate proof of the continued existence of the nomad, and not as a marginalized outsider?

\section{The Expatriate in Time and Space - Scenes from Abroad}

The figure of the nomad is certainly often invoked in discussions of expatriation, exemplified by organizations such as Global Nomads International (Global Nomad Virtual Village, 2006). A major difference between expatriates and traditional nomads is that expatriates operate as individuals. While they may share employment and leisure pursuits with others from time to time, expatriates are singular in their ambitions and trajectory through life. Unlike migrants or refugees, they are defined not by what they are doing, migrating, or seeking refuge, but by what they are outside. It is the ability to stay away from home that defines expatriates. They are literally people who have witdrawn allegiance from their patriota (fellow countrymen). They are singular and anticommunal. Therefore, expatriates arguably possess, in Giorgio Agamben's terms, whatever being, in that their singularity of identity comes from having agency in the contemporary world. Agamben suggests that what is important for the future is to come to a point where "being, as such, matters", whatever it is. "Quodlibet ens is not 'being, it does not matter which,' but rather 'being such that it always matters'” (Agamben, 1993: 1).

In this sense, whatever being is concerned with being in itself, in its own singularity, not in relation to its affiliations with ethnicity, religion or nation. Such singular being might be associated with ethnicity, religion or nation, but it cannot be reduced to it. However, whatever being does not mean an absence of affiliations. Belonging still exists, but it is not a condition of being. While Agamben identifies such singularity in different ways, it can be seen in the state of being an expatriate, who on the one hand is outside patriota and perhaps unable really to return to an archetypal home, but on the other hand is a privileged citizen of the world who is able singularly to come and go anywhere as he or she pleases. The singularity of expatriate interaction with environment means that each contingent and transient moment of their expatriation has a unique quality, and in the absence of a sense of home or belonging, it is the sum of these moments that makes up their whatever being.

Expatriates follow the flows of global commerce. Their movement may not be cyclical or communal, but it is resonant with traditional nomads' following of seasonal pastures. Like them, expatriates are always attuned to the wider world, as well as to their specific location. The difference is that this connection is mediated through technology. As Appadurai has noted, "a mobile and unforeseeable relationship between mass-mediated events and migratory audiences defines the core of the link between globalization and the modern" (1996: 4). As individuals, 
expatriates regularly transcend the local and the global, being embedded in the globalized system of capital that nurtures their peripatetic existence. Their bodily location is connected through electronic media to other locations. Expatriota, they embody the privileged end of a mass of contemporary humanity for whom the limited notions of modernity promulgated by the nation-state have been long overtaken by their own individual connections and aspirations.

Krstic has argued that in a world of instantaneous virtual communication, the traditional desire for travel as a release from the "tyranny of place" has been made redundant. He suggests that physical movement merely replicates what has already been moved by communication systems many times, the lag of the actual body moving in space providing only a hint of what, in earlier times, would have been real steps into the unknown (2003: 25). This argument leads to a somewhat depressing entropic spiral into uniformity of experience, regardless of actual physical position on the globe. In such a world, a person is never quite in a place, but never quite free from place either. This sets up a challenge for architecture. How does it provide a sense of being somewhere, beyond the self-similar environments of Leach's aesthetic cocoons?

The answer may lie in closer examination of the expatriate bodies as they move around the globe ex-patriota. Expatriates do not move randomly. They develop networks of belongings and associations; connections between people, objects, memories and associations. Physical objects that travel with the expatriate - artworks, trinkets, furniture, souvenirs - can develop a talismanic significance as they provide physical points of reference. Such objects denote particular times and places, charting the expatriate's life trajectory by relating the present with other times and places. The role of memory in making such connections is crucial, and provides clues for architecture. As Alberto Pérez-Gómez says, architecture not only matters in such a shifting environment, but it also takes on added responsibility. It needs not just to offer comfortable dwelling but also to be itself memorable, both in the sense of having a space or form that can readily be remembered, and in being a repository of memories (2006: 3). Being memorable in both these senses requires being responsive to the mobile body of the expatriate and to the environment around that body. The reduction of material possessions to essentials can be a liberating thing, but also limiting, not so much in terms of the amount of possessions that can be carried, but the degree to which the uncertain terrain of home can be moved around like baggage.

\section{Form, Memory and the Future of the City}

Cities such as Hong Kong, Shanghai, Jakarta, Tokyo and Bangkok provide some of the traditional haunts of Western expatriation. They also contain a great number of examples of informally creative responses to crowded urban environments. While many of these are not unique to Asia, the growing influence of Asia on the world means that developments in Asian cities have an importance beyond their particular cultures and geographies. The nature of the future city, as a contingent space in which the formal principles of planning and zoning are continually subverted by the weight of transitory humanity, correlates more clearly with the contemporary Asian metropolis than with the more orderly Western model. ${ }^{1}$ As Lee and Lam note in their exploration of future cities in Hong Kong cinema, Asian cities seem to owe far less to the past than their European counterparts (2002: 113). The present generation of Asian city-dwellers is often the first to be
I. It is predicted that in the near future, twenty of the world's biggest cities will be in Asia (Mosquera, 2007: 24). 
completely removed from the agrarian world of their ancestors and far more desirous of developing a new technologically advanced society than returning to their old one.

Future environments have been so often projected as having an Asian flavour that the Japanese academic and cultural critic Toshiya Ueno has used the term techno-orientalism to describe the position of East Asia in Western conceptions of the future (1996: 1). The science-fiction film Blade Runner is an early case in point:

When the architect Lee Ho-yin saw the sci-fi thriller Blade Runner in the mid-nineties, he was surprised about the film reviews that he read. 'A gloomy vision of a big-city future' was the tenor of the American newspapers, because the film was set in dark alleyways between glittering skyscrapers, crowds of people pushed past vegetable stands and collections of disembowelled electrical appliances, raindrops fell from leaky canvas covers, flickering neon lights bathed the passers-by in greenish-grey light. And Lee Ho-yin thought to himself. Future? Vision? This is the future and I am living in it. It is called Hong Kong. (Hanig, 2004: 12)

This future (Blade Runner is set in a future Los Angeles) is portrayed as both exciting and threatening, demonstrating the fascination and the fear with which the West has greeted the growing power of East Asia, as well as the likelihood that its present condition does actually represent the future of the West. Films like Blade Runner allude to one remarkable aspect of Asian cities: the usage that can be made of the tiny spaces left over between buildings. Footpaths, laneways, railway embankments and other marginal locations are often covered with a huge variety of informal uses. Squatter housing squeezes next to railway lines and under bridges. Vendors and service providers occupy footpaths and laneways, sometimes to the point where the permanent buildings can hardly be seen at street level. One of the most distinctive and attractive features of Asian urban environments is the large number of food and drink vendors occupying the streets. Generally occupying mobile or demountable stalls, hawkers set up on footpaths, in alleyways, under bridges. Their structures are simple: a stand on which they prepare their fare, a glass-fronted cabinet to display ingredients, an umbrella for shade. Some provide rudimentary seating and tables and congregate to form small precincts in which several stalls offer a choice to prospective patrons (Fig. 5). In terms of the built environment, these are ephemeral structures, creating a transitory presence that at particular times of the day transforms their often nondescript surroundings into a cornucopia of sights, smells and tastes.

Gutierrez, Portefaix and Ruggeri (2005) and their collaborators have analyzed Hong Kong's compactable market booths. The structures of these booths are festooned with products, creating spaces that are ephemeral but rich with colour, movement and the noise of human activity. In Hong Kong, as elsewhere in Asia, the occupation of spaces can change during the course of the day. Some vendors will set up during daylight hours only to be replaced by different stalls each night, so the whole nature and purpose of a street or district will alter depending on the time of visit (Fig. 6). 


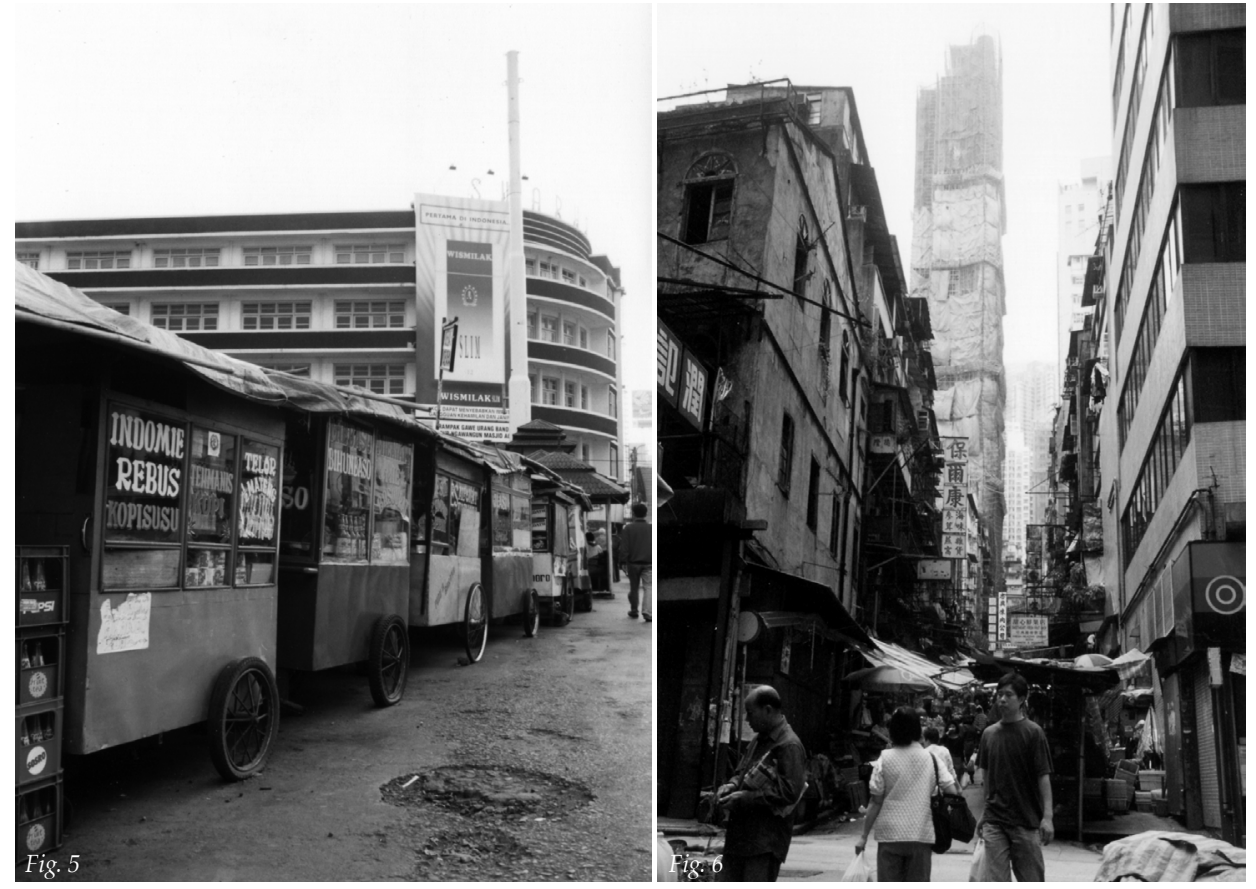

Another group taking a particular interest in this 'micro-urbanism' is Urban Flashes, a loose association of mainly East Asian architects who see the reality of the city as a patchwork of many micro-scale activities and situations in which most people are engaged, as both they and de Certeau (1998) would put it, in tactics rather than strategies, making the most of the limited space and resources at their disposal to make places (Chi, 2003: 18). Ti-Nan Chi, a Taiwanese architect and a leading figure of the group, relates the transience of Asian street life to Sun Tzu's classic Daoist military manual The Art of War (2002: 86). Feints, detours, deception and camouflage are all techniques used by those who make a living on the street in order to cope with the uncertainties of their daily existence. Spaces are appropriated and then vacated when necessary. The nature of the business or inhabitation is always mutable. Even within permanent structures, the nature of spaces changes according to the situation: businesses combine with dwellings, restaurants double as living rooms, and public and private spaces are demarcated by the time of day rather than by territorial boundaries.

Elsewhere in Asia, while the circumstances of settlement may be different, the incremental and tactical nature of much of what is constructed is comparable. While there are Asian cities in which the forces of centralized power have imposed a degree of physical and visual order, this is often subverted. In Jakarta, for instance, grand thoroughfares link the major state monuments. However, apart from these, the city has a shifting and disorientating physical presence, more like a conglomeration of compacted villages than a centrally planned and zoned entity. $^{2}$

Similarly, Isozaki has described the "spatial/performative" rather than "material/constructive" nature of Japanese urban place, where meanings are contingent on events (2006: 66). Illustrative of this is the work of Kaijima, Tsukamoto and their colleagues in the Tokyo Institute of Technology and Atelier Bow-Wow. They have produced guidebooks to pet architecture (tiny buildings on marginal scraps of land) (Tokyo Institute of Technology, Tsukamoto Architectural Laboratory \&
Fig. 5: Temporary food vendors, Bandung, Indonesia. Photograph by David Beynon.

Fig. 6: Street market in Hong Kong. Photograph by David Beynon.

2. This phenomenon has been described as desakota or kampungkota (both Indonesian terms meaning village-city), indicating the dense but de-centralized mix of agricultural and (sub) urban uses that is characteristic of contemporary settlement patterns in Indonesia and elsewhere in Southeast Asia (McGee, 1991; Sihombing, 200I). 
3. While Kaijima, Kuroda and Tsukamoto translate the term da-me as "no-good", they use the term "shameless" to describe in English the characteristics of the same buildings.

4. Lash connects this idea of tactility to the kinds of connections that he identifies in the traditional Japanese city, in which there is little of the hierarchically perspectival layout of the Roman, Baroque or modernist city. He argues that this tactility has a linguistic basis. $\mathrm{He}$ notes that there is not in the Japanese language a clear causal relationship between actions and events, but instead a topological relationship in which meaning is derived from connections within a shared context.

Fig. 7: 'Pet architecture' in Shibuya, Tokyo, Japan. Photograph by David Beynon.

Fig. 8: Da-me architecture in Osaka, Japan. Photograph by David Beynon.
Atelier Bow-Wow, 2002) and da-me or "no-good" architecture (hybrid typologies such as a spaghetti stand-baseball batting centre, a railway bridge-shopping arcade, a taxi garage-golf driving range, a concrete plant-company housing block, a supermarket-driving school) (Kaijima, Kuroda \& Tsukamoto, 2001).

They describe the kinds of "shamelessly" pragmatic buildings that, contrary to the impression given by architectural journals, actually predominate in Tokyo and other Japanese cities (Figs. 7 and 8). Furthermore, rather than bemoaning an urban environment full of such buildings, they look for ways in which their "shameless" character might lead to a better understanding of their urban environment. ${ }^{3}$ As they see it, such practical interdependent solutions to the crowding and chaos of the city dissolve the categories of 'high' architecture in favour of a continuum between uses and building types. Instead of architecture, Kaijima et al prefer the term "environmental unit", suggesting that in the ingenuity of purpose and spatial usage embodied in these buildings, architecture operates within the context of the city on an individualized, singular level, in creatively using the gaps between and around the city's edifices and monuments (Kaijima et al, 2001: 8). Isozaki contends that this kind of architecture - with its meaning derived from signs, usage and transitory happenings - is increasingly commonplace everywhere in the contemporary world (2006: 68). Following on from this, Lash argues that orientating oneself in a contemporary environment of intermeshed real and virtual spaces makes traditional notions of city legibility less important, replaced by what he describes as tactility - the ability to connect in an immediate and individual sense to both locality and globalized forces (1999: 58). ${ }^{4}$
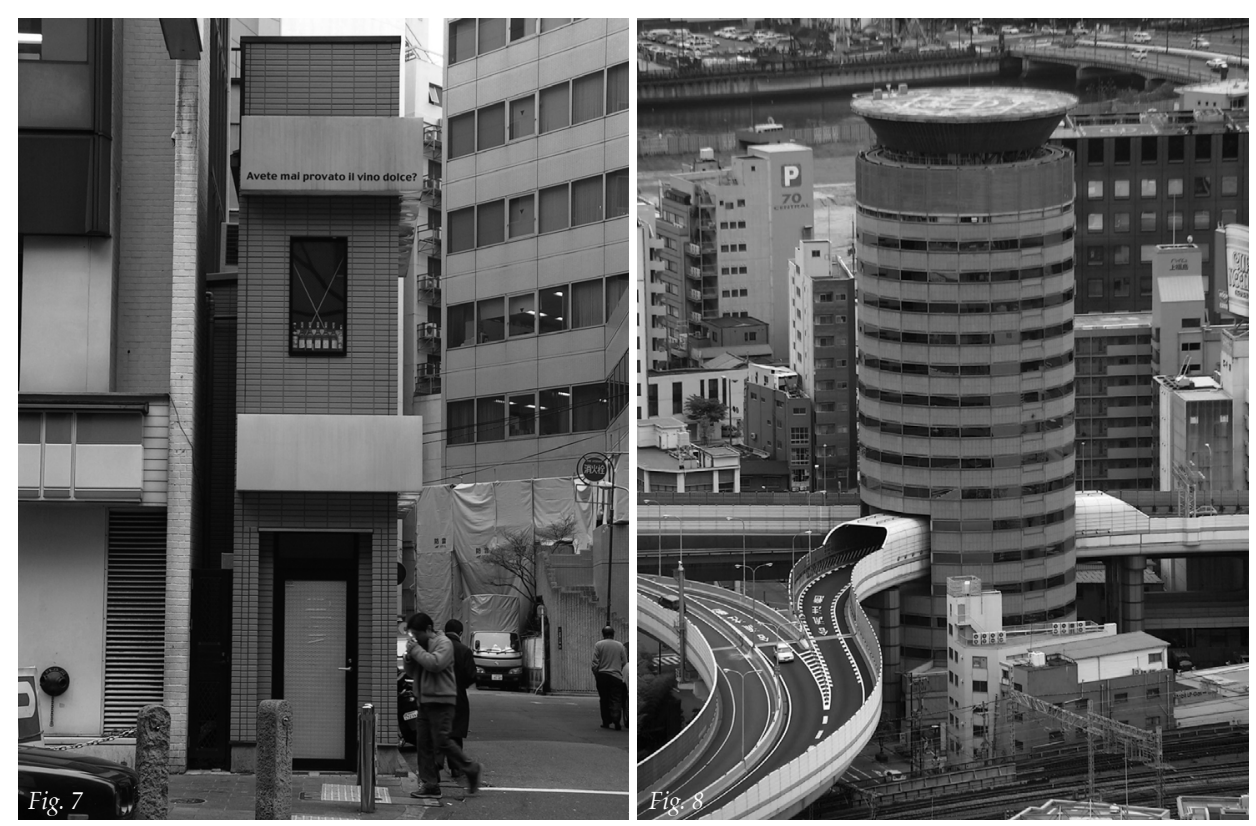

These examples suggest a particular way of looking at the city. There is an absence in their discussions of any overarching order, aesthetic or otherwise. There is no sense that anything fundamental about the structure of the city is alterable by its inhabitants. The city just is, and must be negotiated like any other environment, with local knowledge about its resources and its dangers used tactically to allow comfortable inhabitation within it. Expatriates have certain advantages in such an environment. Their capital provides for a level of comfort and freedom 
from the dangers likely to be suffered by many of the inhabitants of the buildings described by Gutierrez, Portefaix, Kaijima, Tsukamoto, Chi and others. However, they have the same ephemerality of tenure. Their connection with place is uncertain. They are ex-patriota, outside their 'natural' home. No matter how comfortable they may be in their adopted environment, they find it difficult to escape questions of origin and allegiance.

\section{Architectural Implications - At Home or Adrift in the World?}

But fear not, urban nomad, the house of the future comes with you.

The comforts of home are compactable and transportable, readily relocatable to your new work or recreational environment. (AlsoCAN Architects with Multiplicity, 1999a, 1999b)

Being at home ex-patriota thus requires a coexistence of three things. The first is the ability of a transitory abode to function as a repository of memories. The second is the ability to make use of the opportunities of any environment. The third is to develop a whatever singularity that cannot be entrapped by any one sense of belonging, that, paradoxically, is willing to risk being out of place to be at home any where. The Slinky House may not provide all of these, but it attempts

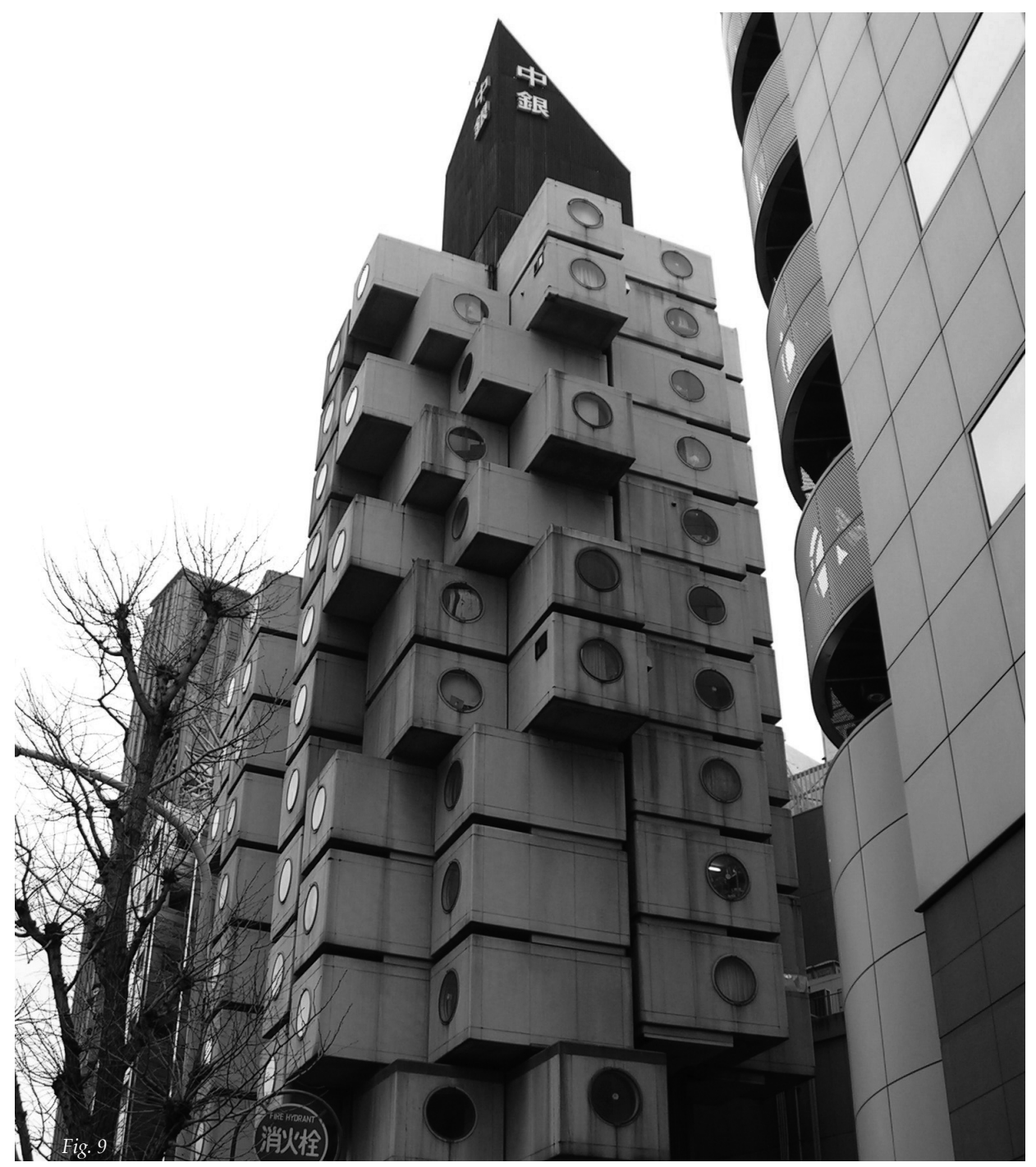


5. The idea that the Slinky House would be able to support its building host (in ways that admittedly would take a lot of research and development) through water collection and the harvesting of solar energy was conceived within this context. If we were to seriously revisit the project in 2008 , these aspects would be further developed. to make connections between the body of the urban nomad, the broad environment of expatriate mobility, and the specific functional and aesthetic requirements of location (Fig. 9).

In a pragmatic sense, the Slinky House relates to other architectural attempts to achieve mobility, in particular the work of the Metabolists in Japan. Metabolism attempted to combine modernist ideals of technological advancement with notions of spatial and formal mutability that derived from Japanese traditions and contemporary conditions of rapid industrial development. Metabolist architecture combined infrastructural frames (containing circulation, structure and services) with autonomous modular units that, in theory, could be plugged into or removed from the frame as required by a changing society (Reynolds, 2001: 227). The living pods of Kurokawa's Nakagin Capsule Building, for example, could be reconfigured on other sites, as suggested by his own Karuizawa Capsule House (Kurokawa, 1991: 126; Stewart, 2002: 184).

Like a Metabolist pod, the Slinky House would also ideally be an ephemeral presence in any one location, though, as any observer of the history of Metabolist buildings would note, architecture's urge to permanence is not easily subverted. However, a key difference between the Slinky House and its Metabolist or other modernist antecedents is that it is not Utopian. The Slinky House accepts the city as it is. ${ }^{5}$ It posits a relationship between expatriates and urbanity based neither on isolation, nor on the envisaging of a brave new world. Instead, it seeks to work on the level of the incremental. This response to the urban environment - while marked by the privileged status of their inhabitants - is akin to the tactical responses of other itinerant city dwellers (Mosquera, 2007: 23). Functionally it blurs the physical boundaries between home and work, though unlike the prevalent contemporary model that seeks to convert the home into a workplace, it appropriates the space adjacent to the workplace for dwelling. Apart from shelter, the building is intended to provide an armature that would allow its inhabitant to engage comfortably with the changing reality of its surrounding; to be memorable as well as providing an envelope for the transportation of memories. As an object-image, it mediates between architecture and more ephemeral aspects of urban life: street art, demountable stall or festive decoration. Expatriate living in the future is likely, in the author's view, to involve either physical isolation within secure enclaves of privilege or engaging tactically with the shifting context of the future megalopolis. The latter needs to remain an option.

\section{References}

Agamben, G. (1993). The Coming Community. Minneapolis: University of Minnesota Press. AlsoCAN Architects in conjunction with Multiplicity (1999a). 'Slinky House' competition submission.

AlsoCAN Architects in conjunction with Multiplicity (1999b). Monument, (29), 42-43.

Appadurai, A. (1996). Modernity at Large: Cultural Dimensions of Globalisation. Minneapolis: University of Minnesota Press.

Augé, M. (1995). Non-places: Introduction to an Anthropology of Supermodernity. London: Verso.

Bourdieu, P. (1993). The Field of Cultural Production: Essays on Art and Literature. New York: Columbia University Press.

Chi, T.-N. (2002). Introduction: Tactic. In T.-N. Chi (Ed.), Urban Flashes (pp. 86-120). Taipei: Human Environment Group. 
Chi, T.-N. (2003). Introduction to Micro-Urbanism. In N. Boyarsky \& P. Lang (Eds.), Urban Flashes Asia: New Architecture and Urbanism in Asia (pp. 16-21). Chichester: Wiley.

de Certeau, M. (1998). The Practice of Everyday Life. Minneapolis: University of Minnesota Press.

Douglas, M. (1966). Purity and Danger: An Analysis of Concepts of Pollution and Taboo. London: Routledge \& Kegan Paul.

Global Nomad Virtual Village (2006). Retrieved April 21, 2008 from www.gnvv.org/ AboutUs.htm

Gutierrez, L., Portefaix, V., \& Ruggeri, L. (Eds.) (2005). HK LAB 2: An Exploration of Hong Kong Interior Spaces. Hong Kong: MAP.

Hanig, F. (2004). Neon Cities. In P. Bialobrzeski (Ed.), Neontigers: Photographs of Asian Megacities (pp. 12-17). Ostfildern-Ruit: Hatje Cantz.

Home of the Future Competition (1999). Architect Victoria, (March), 12-13.

Isozaki, A. (2006). Japan-ness in Architecture. Cambridge (Mass.): MIT Press.

Kaijima, M., Kuroda, J., \& Tsukamoto, Y. (2001). Made in Tokyo. Tokyo: Kajima.

Krstic, V. (2003). About other Constructs and Spaces. In R. Kronenburg (Ed.), Transportable Environments 2: Theory, Context Design and Technology (pp. 25-31). London: Spon.

Kurokawa, K. (1991). Intercultural Architecture: The Philosophy of Symbiosis. Washington (DC): The American Institute of Architects Press.

Lash, L. (1999). Another Modernity, A Different Rationality. Oxford: Blackwell.

Leach, N. (2002). Urban Camouflage. In T.-N. Chi (Ed.), Urban Flashes (pp. 234-37). Taipei: Human Environment Group.

Lee, G., \& Lam, S. (2002). Wicked Cities: The Other in Hong Kong Science Fiction. In Z. Sardar \& S. Cubitt (Eds.), Aliens R Us: The Other in Science Fiction Cinema (pp. 111-33). London: Pluto.

McGee, T. (1991). The Emergence of Desakota Regions in Asia: Expanding a Hypothesis. In N. Ginsberg, B. Koppel \& T. McGee (Eds.), The Extended Metropolis: Settlement Transition in Asia (pp. 3-35). Honolulu: University of Hawaii Press.

Mosquera, G. (2007). The Urban Revolution. In A. van Helmond \& S. Michiels (Eds.), Jakarta Megalopolis: Horizontal and Vertical Observations (pp. 22-24). Amsterdam: Valiz.

Museum Victoria (1999). Home of the Future Design Competition. Melbourne: s.p.

Pérez-Gómez, A. (2006). Polyphilo's Thresholds: Alternatives for Nomadic Dwelling. In R. Kronenburg (Ed.), Transportable Environments 3: Theory, Context Design and Technology (pp. 2-9). London: Spon.

Reynolds, J. (2001). Maekawa Kunio and the Emergence of Japanese Modernist Architecture. Berkeley: University of California Press.

Sihombing, A. (2001). Drawing the City: Revealing People's Awareness of Kampungkota Jakarta. In International Seminar on Urbanization in the Information Age: New Perspectives on the Transformation of Fast Growing Cities in the Pacific Rim (pp. 6-4, 6-5). Depok: Universitas Indonesia.

Stewart, D. (2002). The Making of a Modern Japanese Architecture: From the Founders to Shinohara and Isozaki (Edition with New Preface). Tokyo: Kodansha International.

Tokyo Institute of Technology, Tsukamoto Architectural Laboratory and Atelier Bow-Wow (2002). Living Spheres Volume 2: Pet Architecture Guide Book. Tokyo: World Photo Press.

Ueno, T. (1996). Japanimation and Techno-Orientalism: Japan as the Sub-Empire of Signs. Documentary Box, 9. 